УДК 631.162:338.434

DOI: https://doi.org/10.37320/2415-3583/9.7

Салогуб I.I.

здобувач кафедри фінансів і кредиту, Полтавська державна аграрна академія ORCID: https://orcid.org/0000-0002-7853-4841

\title{
КРЕДИТУВАННЯ АГРАРНОГО ВИРОБНИЦТВА: ОСОБЛИВОСТІ, ПРОБЛЕМИ, НАПРЯМИ РОЗВИТКУ
}

У статті проведено визначення особливостей, проблем та здійснено обтрунтування напрямів розвитку системи кредитування аграрного виробництва в сучасних умовах. Виявлено чинники, які забезпечують привабливість аграрних товаровиробників для банківського капіталу: наявність стабільного попиту на сезонні кредити, наявність обмежених джерел внутрішнього нагромадження, тривалий иикл і локалізація в просторі виробнииттва продукиії, прив'язка бізнесу до земельних ресурсів. Визначено чинники, щзо створюють бар'єри для проникнення на ринок капіталу, викликані об'єктивними особливостями, такі як: багатоукладність аграрного виробництва, відсутність досвіду $i$ традииій комериійного кредитування, суперечливість $i$ недостатність законодавства. Установлено, щзо з урахуванням специфічних особливостей аграрного виробництва система кредитування аграрних товаровиробників повинна пропонувати кредити різних форм на базі забезпечення взаємних інтересів сторін, зростання ефективності виробництва і нових методичних підходів до даної галузі з боку фінансово-кредитних інститутів.

Ключові слова: кредитування, аграрне виробництво, державне регулювання, ефективність, стимулювання.

Постановка проблеми. У сучасних умовах аграрні товаровиробники стикаються у своїй діяльності зі значними труднощами. Однією 3 них є дефіцит обігових коштів для здійснення господарської діяльності. В умовах сезонності і тривалості виробничого циклу в сільському господарстві наслідки цього явища позначаються більш згубно, ніж в інших галузях економіки. Зважаючи на неможливість забезпечення потреби в обігових коштах за рахунок власних джерел виникає об'єктивна потреба в залученні коштів зі сторони. Проте це стримується обмеженою доступністю кредитних коштів для аграрних виробників. Забезпечення доступності ресурсів значною мірою пов'язано із взаємодією держави, комерційних банків і кредитних кооперативів. 3 огляду на нерозвиненість сільськогосподарської кредитної кооперації, основним джерелом забезпечення аграрних товаровиробників залишаються комерційні банки, але механізм їх взаємодії також вимагає вдосконалення з урахуванням особливостей аграрного виробництва та світового досвіду. Внаслідок цього перед аграрними товаровиробниками гостро стоїть проблема надійних джерел позикових коштів, у тому числі можливість кредитування в комерційних банках. 3 урахуванням слабкого розвитку системи аграрного кредиту необхідна також активна участь держави в забезпеченні кредитними ресурсами виробників аграрного сектору економіки країни.

Аналіз останніх досліджень і публікацій. Теоретико-методологічні та прикладні аспекти розвитку системи кредитування аграрного виробництва та суб'єктів господарювання галузі досліджено і висвітлено у роботах багатьох вітчизняних уче- них. Значний внесок у розгляд цього питання, на нашу думку, зробили: Ю. Алескерова [1], В. Аранчій [2], О. Гудзь [3], М. Дем'яненко [4], О. Зоря [2; 5], Г. Калетнік [6], Ю. Лупенко [5], О. Малій [8], М. Малік [5], О. Непочатенко [7], Н. Правдюк [9], П. Саблук [8], П. Стецюк [12], О. Шпикуляк [5] та багато інших. Незважаючи на значну кількість досліджень із даної проблеми, багато теоретичних та методичних питань, пов'язаних із визначенням особливостей, проблем та обгрунтуванням напрямів розвитку системи кредитування аграрного виробництва в сучасних умовах, залишаються не до кінця вивченими, що і зумовило актуальність та необхідність даного дослідження.

Мета статті полягає у визначенні особливостей, проблем та обгрунтуванні напрямів розвитку системи кредитування аграрного виробництва в сучасних умовах. Відповідно до цього, завданнями дослідження є:

- визначити особливості та специфіку кредитування аграрного виробництва;

- виділити специфічні ризики, які впливають на розвиток кредитування в аграрному секторі економіки;

- обгрунтувати чинники, які роблять аграрних товаровиробників привабливими для банківського капіталу;

- запропонувати основні загальні напрями вдосконалення організації кредитування аграрних підприємств;

- визначити об'єкти і напрями кредитної підтримки інноваційного розвитку аграрних підприємств.

Виклад основного матеріалу. Найважливішим завданням забезпечення продовольчої без- 
пеки України є стабільний розвиток вітчизняного виробництва сільськогосподарської продукції, сировини і продовольства. У зв'язку із цим виробництво якісної продукції сільського господарства $€$ одним із ключових завдань галузі, а розширене відтворення - основою ефективного функціонування аграрного сектору.

Аграрний сектор є основною продовольчою галуззю національної економіки, стан якої прямо пропорційно залежить від обсягів коштів, вкладених у іiі розвиток, зокрема від інтенсивності інвестиційної діяльності. Активна інвестиційна діяльність підприємств аграрного сектору - запорука їхнього стабільного розвитку й досягнення очікуваних результатів. Від обсягів інвестицій залежать матеріально-технічний стан підприємств, забезпеченість ресурсами, якісний склад трудових ресурсів, кількість продукції, а також рівень прибутковості. Саме прибуткові підприємства можуть бути активними учасниками не лише інвестиційного процесу в країні, а й найбільш привабливими суб'єктами кредитних відносин [2, с. 120].

Здійснення інвестицій у розвиток аграрного виробництва можливе як за рахунок власних коштів, так і залучених. Проте власні кошти не завжди можливо вкласти у виробництво. Із цією проблемою стикаються багато аграрних товаровиробників, що пов'язано зі специфікою самої сфери діяльності - низька рентабельність та значні природно-кліматичні ризики. Підвищена ризикованість одержання стабільних фінансових результатів від господарської діяльності, низька кредитоспроможність підприємств галузі також перешкоджають розвитку кредитних відносин, адже банки бажають бачити в позичальниках лише прибуткових клієнтів [8]. Державна підтримка аграрного виробництва у більшості країн світу $є$ пріоритетним напрямом їхньої аграрної політики. Вона є одним із міцних зовнішніх джерел формування фінансових ресурсів аграрних підприємств [12].

Серйозними чинниками, які обмежують кредитування аграрного виробництва, є специфічні ризики, з якими банки стикаються під час кредитування даної галузі. До специфічних ризиків кредитування аграрних товаровиробників нами віднесено такі:

- підвищена нестійкість фінансового стану підприємств аграрного сектору;

- невідповідність довгострокових запитів підприємств короткостроковості наявних у банків ресурсів;

- сезонні особливості сільськогосподарського виробництва, його залежність від природно-кліматичних умов;

- труднощі, пов'язані з реалізацією продукції;

- відсутність у позичальників ліквідного забезпечення кредитів;
- низька прибутковість операцій із кредитування аграрного виробництва;

- недостатня правова та нормативна база кредитування сільського господарства.

Незважаючи на названі проблеми, які обмежують доступність кредитних ресурсів, у аграрних товаровиробників існують також чинники, що роблять їх привабливими для банківського капіталу. До них, на нашу думку, можна віднести такі:

- наявність стабільного попиту на сезонні кредити, пов'язані з проведенням посівних і збиральних робіт. Це дає змогу банкам прогнозувати виникнення потреби в кредитних ресурсах і відповідним чином формувати свою фінансову політику;

- у аграрних товаровиробників обмежені джерела внутрішнього накопичення, тому здійснення інвестицій в основний капітал передбачає залучення банківського кредиту;

- виробництво продукції в сільському господарстві має досить довгий цикл, локалізовано в просторі, а отже, зручніше для банківського контролю, ніж, наприклад, комерційні операції роздрібного торговця. За необхідності банку простіше взяти під контроль реалізацію врожаю зерна, ніж рух багатьох видів несільськогосподарської продукції;

- аграрний бізнес нерозривно пов'язаний із використанням земельних ресурсів. Це надає кредитним угодам більш стійкий характер. Окрім іпотечного кредитування (для якого нині в нашій країні тільки формуються необхідна практика i процедури), це створює додаткові гарантії повернення кредитів.

Особливості процесу відтворення в аграрному виробництві не дають змоги функціонувати тільки за рахунок власних джерел фінансування. Йому потрібна фінансово-кредитна державна підтримка, оскільки власних коштів аграрних товаровиробників недостатньо навіть для здійснення сезонних робіт, виконання розрахунків із бюджетом, по заробітній платі, придбання сільськогосподарської техніки, утримання соціально-культурної сфери.

Відповідно до цього, на нашу думку, необхідне розроблення нового механізму дотаційної бюджетної підтримки аграрного виробництва, спрямованої на його ефективне функціонування. У нинішніх умовах такими вимогами, на нашу думку, можуть бути: збереження посівних площ і поголів'я тварин на існуючому рівні або збільшення цих показників, виконання договірних зобов'язань поставок продукції у продовольчі фонди, здійснення інвестицій у виробництво, погашення заборгованості тощо. Аграрні підприємства можуть виконувати або не виконувати ці вимоги, але у разі невиконання вони позбавляються фінансової бюджетної допомоги. Уважаємо 
такий спосіб утручання держави в справи аграрного сектору справедливим в умовах ринкової економіки. Він стимулює активність аграрних товаровиробників і сприяє економічному зростанню у цій сфері економіки. Комплексне дотримання викладених принципів, безумовно, нівелює негативні риси існуючого механізму бюджетної підтримки аграрного виробництва. Пільгове кредитування також може стати важливим методом стимулювання інноваційної діяльності аграрних товаровиробників (рис. 1).

Об'єктом стимулювання при цьому повинні стати наукова та інноваційна діяльність та інноваційна зацікавленість аграрного сектору економіки, визнана суспільно пріоритетною, напрями якої визначаються державою, фінансуються в непрямому порядку з бюджету і контролюються відповідними органами виконавчої влади. Система кредитного стимулювання повинна сприяти вирішенню двоєдиного завдання держави в сільському господарстві: загальної активізації застосування інновацій, забезпечення структурної перебудови і підвищення конкурентоспроможності підприємств. За допомогою гнучкої системи кредитного стимулювання можливе досягнення оптимального співвідношення між бюджетним фінансуванням науки і самофінансуванням науково-технічного прогресу.

Підводячи підсумки, можна виділити основні загальні напрями щодо вдосконалення організації кредитування аграрних підприємств:

- для підвищення ефективності кредитів необхідно збільшити видатки держави на підтримку аграрних товаровиробників;

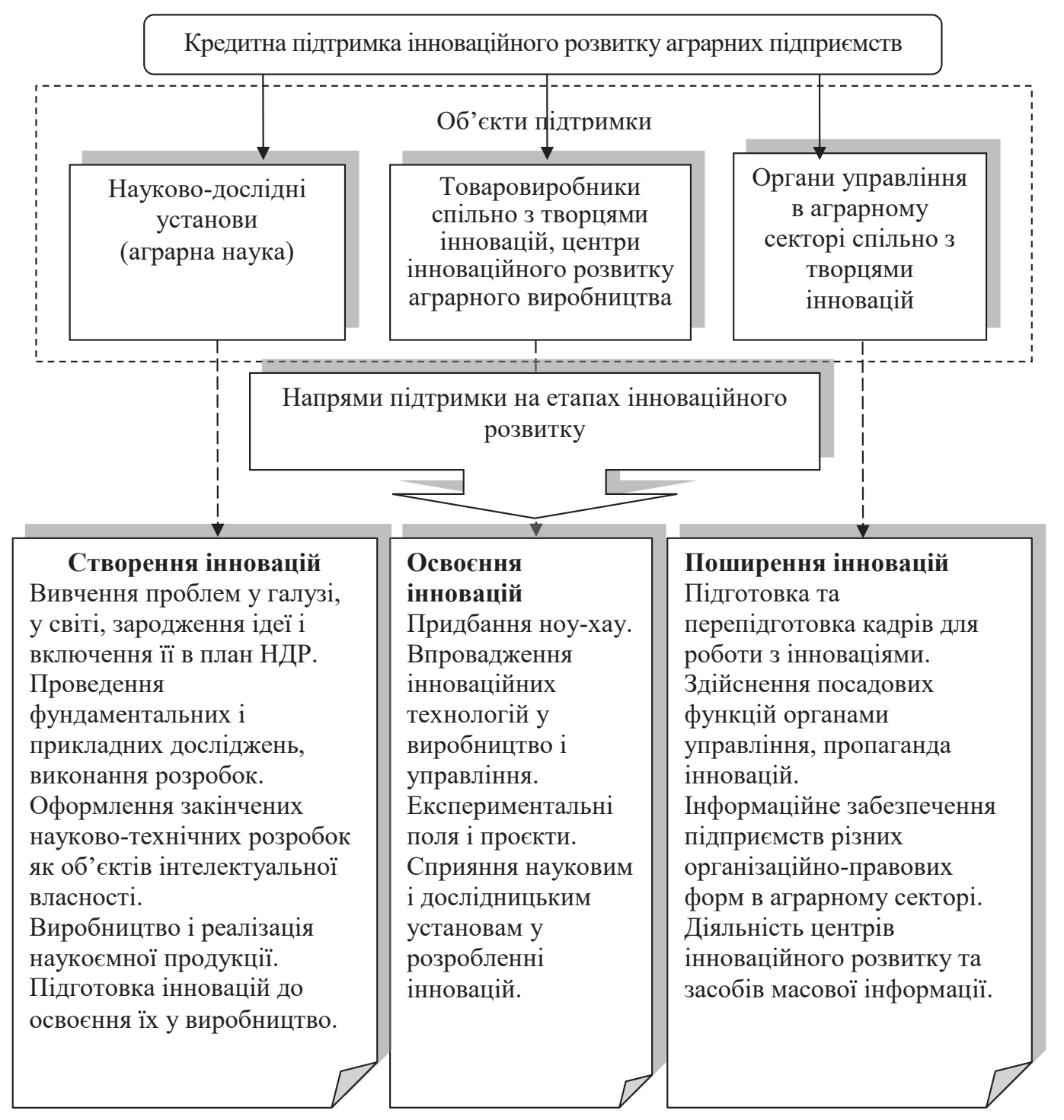

Рисунок 1 - Пільгове кредитування як метод стимулювання інноваційної діяльності аграрних товаровиробників

Джерело: побудовано автором на основі [5, с. 163] 
- необхідно зробити відкритими методологічні розробки вітчизняних банків для зовнішнього середовища, щоб вони публічно обговорювалися на сторінках фахових журналів, що дає змогу ідентифікувати допущені співробітниками банків помилки, включаючи недоліки в методичному, організаційному, кадровому та технічному забезпеченні аналітичної роботи, і попереджати їх виникнення в майбутньому;

- виключити з процесу кредитування «особистісний фактор»;

- створити єдину нормативно-методологічну базу кредитного процесу.

Висновки. Таким чином, у роботі виявлено чинники, які забезпечують привабливість аграрних товаровиробників для банківського капіталу. До них відносяться: наявність стабільного попиту на сезонні кредити, наявність обмежених джерел внутрішнього нагромадження, тривалий цикл і локалізація в просторі виробництва продукції, прив'язка бізнесу до земельних ресурсів. Окрім того, визначено чинники, що створюють бар'єри для проник- нення на ринок капіталу, викликані об'єктивними особливостями. До них відносяться: багатоукладність аграрного виробництва, відсутність досвіду i традицій комерційного кредитування, суперечливість та недостатність законодавства. 3 урахуванням специфічних особливостей аграрного виробництва система кредитування аграрних товаровиробників повинна пропонувати кредити різних форм на базі забезпечення взаємних інтересів сторін, зростання ефективності виробництва i нових методичних підходів до даної галузі з боку фінансово-кредитних інститутів. Створення комплексного механізму кредитного стимулювання інноваційної діяльності в сільському господарстві - сфері, яка характеризується високим ступенем ризику і невизначеності, дасть змогу активізувати науково-технічний прогрес по всьому ланцюжку - від фундаментальних досліджень до впровадження розробок у виробництво 3 урахуванням обмеженості ресурсів підприємств і державних (суспільних) пріоритетів розвитку галузі й забезпечити сталий розвиток галузі в перспективі.

\section{Список використаних джерел:}

1. Алескерова Ю.В. Державне регулювання фінансових процесів в агропромисловому комплексі. Причорноморські економічні студіi. 2016. Вип. 11. С. 209-214.

2. Аранчій В.І., Зоря О.П., Петренко I.I. Кредит у системі фінансового забезпечення інвестиційного розвитку аграрних підприємств. Вісник Полтавської державної аграрної академії. 2011. № 4. С. 120-124.

3. Гудзь О.С. Проблеми удосконалення державної фінансової підтримки підприємств агропромислового комплексу через механізм здешевлення кредитів. Облік і фінанси АПК. 2005. № 6. С. 18-26.

4. Дем'яненко М.Я. Кредитний фактор сталого розвитку аграрного сектору України. Економіка АПК. 2014. № 11. С. 5-14.

5. Зоря О.П. Управління розвитком аграрних підприємств в умовах інституційних трансформацій : монографія. Полтава, 2019. $321 \mathrm{c.}$

6. Інноваційне забезпечення розвитку сільського господарства України: проблеми та перспективи / Ю.О. Лупенкота ін. Київ : ННЦ «IAЕ», 2014. 516 с.

7. Калетнік Г.М., Ціхановська В.М. Фінансовий менеджмент : навчальний посібник. Київ : Хай-Тек Пресс, 2010. $317 \mathrm{c}$.

8. Малій О.Г. Фінансово-кредитні відносини в АПК : монографія. Харків, 2008. 210 с.

9. Непочатенко О.О. Державна підтримка підприємств АПК через удосконалення системи кредитування. Економіка АПК. 2008. № 8. С. 95-100.

10. Організаційно-економічна модернізація аграрної сфери: наукова доповідь / за заг. ред. акад. НААН П.Т. Саблука. Київ : ННЦ ІАЕ, 2011. 342 с.

11. Правдюк Н.Л. Аграрні розписки як альтернативна форма кредитування сільськогосподарських підприємств: обліковий аспект. Облік і фінанси. 2016. № 4. С. 69-79.

12. Стецюк П.А. Стратегія і тактика управління фінансовими ресурсами сільськогосподарських підприємств : монографія. Київ : ННЦ «ІАЕ», 2009. 370 с.

\section{References:}

1. Aleskerova, Ju.V. (2016), Derzhavne reguljuvannja finansovyh procesiv v agropromyslovomu kompleksi [State regulation of financial processes in the agro-industrial complex]. Prychornomors'ki ekonomichni studii', 11, 209-214 [in Ukrainian].

2. Aranchii V.I., Zoria O.P., \& Petrenko I.I. (2011). Kredyt u systemi finansovoho zabezpechennia investytsiinoho rozvytku ahrarnykh pidpryiemstv [Credit in the system of financial provision of investment development of agrarianenterprises]. Visnyk Poltavs'koi' derzhavnoi' agrarnoi' akademii', No 4, p. 120-124 [in Ukrainian].

3. Gudz, O.Ye. (2005), Problemi udoskonalennya derzhavnoyi finansovoyi pidtrimki pidpriyemstv agropromislovogo kompleksu cherez mehanizm zdeshevlennya kreditiv [Problems of improvement of state financial support of enterprises of agroindustrial complex through the mechanism of cheapening of loans] Oblik i finansi APK, 6, 18-22 [in Ukrainian].

4. Dem'yanenko, M.Ya. (2014). Kredytnyj faktor stalogo rozvytku agrarnogo sektoru Ukrai'ny [Credit factor of sustainable development of the agrarian sector of Ukraine]. Ekonomika APK, 11, 5-14 [in Ukrainian].

5. Zoria O.P. (2019). Upravlinnya rozvytkom ahrarnykh pidpryyemstv $v$ umovakh instytutsiynykh transformatsiy [Management of development of agricultural enterprises in the conditions of institutional transformations], Poltava, Ukraine. 321 s. [in Ukrainian]. 
6. Lupenko, Yu. O., Malik, M. J., Shpykuliak, O. H. and other (2014), Innovatsijne zabezpechennia rozvytku sil's'koho hospodarstva Ukrainy: problemy ta perspektyvy [Innovative software of development of agriculture Ukraine: Problems and Prospects], Institute of Agrarian Economy, Kyiv, Ukraine. 516 s. [in Ukrainian].

7. Kaletnik, H.M., Tsikhanovska, V. M. (2010), Finansovyi menedzhment: navch. posib. dlia stud. VNZ [Financial management]. Kyiv: Khai-Tek Press. 317 s. [in Ukrainian].

8. Maliy O.G. (2008). Finansovo-kredytni vidnosyny v APK [Financial and credit relationsin the agroindustrial complex]. Kharkiv, 210 s. [in Ukrainian].

9. Nepochatenko, O.O. (2008), Derzhavna pidtrymka pidpryjemstv APK cherez udoskonalennja systemy kredytuvannja [State support of agroindustrial complexes through improvement of lending system]. Ekonomika APK, 8, 95-100 [in Ukrainian].

10. Sabluk, P.T. (2011), Orhanizatsiyno-ekonomichna modernizatsiya ahrarnoyi sfery [Organizational and economic modernization of the agricultural sector]. Kyiv: NNTs IAE, 342 s. [in Ukrainian].

11. Pravdiuk, N.L. (2016), Ahrarni rozpysky yak alternatyvna forma kredytuvannia silskohopodarskykh pidpryiemstv: oblikovyi aspekt [Agrarian receipts as an alternative form of crediting agricultural enterprises: accounting aspect]. Oblik i finansy, 4, 69-79 [in Ukrainian].

12. Stetsiuk P.A. (2009). Stratehiia i taktyka upravlinnia finansovymy resursamy silskohospodarskykh pidpryiemstv [Strategy and tactics of management of financial resources of agricultural enterprises]. Kyiv, $370 \mathrm{~s}$. [in Ukrainian].

\author{
Salohub Iryna \\ Poltava State Agrarian Academy
}

\title{
LENDING TO AGRICULTURAL PRODUCTION: FEATURES, PROBLEMS, AREAS OF DEVELOPMENT
}

Agrarian producers face the problem of reliable sources of borrowing, including the possibility of lending to commercial banks. Taking into account the weak development of the agricultural credit system, active participation of the state in providing credit resources to agricultural sector producers in the country's economy is also required. The article defines the features, problems and substantiates the directions of development of the agricultural crediting system in modern conditions. The paper identifies the factors that make agricultural commodities attractive to bankers: stable demand for seasonal loans, limited internal sources of accumulation, a long cycle and localization in the space of production, anchoring of businesses to land resources. The factors that create barriers to the penetration of the capital market, caused by objective features, such as the complexity of agricultural production, lack of experience and traditions of commercial lending, contradiction and lack of legislation are identified. It is established that, taking into account the specific features of agricultural production, the credit system of agricultural commodity producers should offer loans of various forms on the basis of mutual interests of the parties, increase of production efficiency and new methodological approaches to this branch by financial and credit institutions. It is determined that the features of the process of reproduction in agricultural production do not allow to operate only at the expense of own sources of financing. He needs financial and credit state support, since the agricultural producers' own funds are not enough even for seasonal work, payments with the budget, wages, purchase of agricultural machinery, maintenance of socio-cultural sphere. It is determined that the creation of a comprehensive mechanism for credit stimulation of innovative activity in agriculture will allow to activate scientific and technological progress along the chain, from basic research to implementation of development in production, taking into account the limited resources of enterprises and state (public) priorities for the development of the industry, development of the industry in the future. The practical significance of the study lies in the fact that its scientific-theoretical results, practical proposals, conclusions and generalizations form the scientific basis for the development of directions of state regulation of the credit system in agricultural production. The implementation of the proposed measures will help to increase the efficiency of agricultural production and ensure the process of sustainable development of the agricultural sector of the economy.

Key words: crediting, agrarian production, state regulation, efficiency, incentives.

JEL classification: Q14. 